\title{
FRP ハニカムサンドイッチ構造の環境クリープ特性
}

\section{Creep Properties of FRP Sandwich Construction in Simulated Soil Environment}

by

\author{
Hiroo MrYaIRI* and Okiyo SuDA**
}

Fiber reinforced plastic (FRP) materials composed of glass/unsaturated polyester (GF/UP) are used in many fields because of their good properties. In this paper, the fiber reinforced plastic honeycomb sandwich construction made of GF/UP composites was investigated to examine its applicability as structural parts for underground use by utilizing its high flexural rigidity and high corrosion resistance. The creep tests were carried out by dipping the pamples in alkali buffer solution simulating the condition of under-ground water. The creep properties of FRP honeycomb sandwich construction were examined in flexural mode. The fracture appeared in the flexural or shear mode pattern depending on the loading conditions. The experimental results clarified the creep properties of the material and provided an important information about creep design for the application of FRP honeycomb sand. wich structure in underground water.

Key words : FRP honeycomb sandwich, Flexural creep test, Endurance limit, Fracture pattern, Alkali buffer solution

\section{1 緒 言}

ガラス瀻維 $(\mathrm{GF})$ と不飽和ポリエルテル (UP) で構成される GF/UP 複合材は瀻維強化プラスチッ ク（FRP）の成形性の優れた特徵を活用してさまざ まな積層構成の構造体に応用されている。 その最も一 般的なものは FRP 積層板であるが，構造的なメリッ トを活したものとしサンドイッチ構造やスチフナー構 造と称せられるものも多く $く^{4), 5)}$ 特にハニカムコアを FRP で成形した FRP 製ハニカムサンドイッチ構造 などはFRP の特徵を活した典型的なサンドイッチ構 造である。 こ このような構造体は軽量でかつ剛性の高い ことから軽量ブロックとして広く用いられて抢り，そ のような中でも耐食性を活した地下埋設用の素材とし て FRP は土木，建築の分野でも広く応用されつつあ る. しかしこのような FRP ハニカムサンドイッチ板 に関する土中環境下でのクリープ特性について検討し た報告はほとんど見当らない，したがって，ここでは このような FRP 製ハニカムサンドイッチ板の地下埋 設時の劣化挙動を調べるため, 地下水中に浸漬された 負荷状況を想定したクリープ試験を行ない，材料のク リープ特性についての検討を行なった，実験では土中 での地下水液中の特殊環境を想定して $\mathrm{pH} 9 \sim 9.4$ の アルカリ緩衝液を用い，溶液中で $10^{3}$ 時間程度までの
クリープ試験を行ない，サンドイッチ板に加わる応力 を曲げ応力とせん断応力に分けて検討した．またこの ような結果を用い，負荷時間 $10^{6}$ 時間（114 年相当） に相当するクリープ寿命の推定について検討したもの で，その結果をここに報告する。

\section{2 ハニカムサンドイッチ材の構成と} 材料特性

FRP 製ハニカムサンドイッチ板はガラスチョップ ドストランドマット（旭ファイバーグラス社製，品名 CM385，3.8 N/m $\mathrm{m}^{2}$ ) と不飽和ポリエステル（日本触 媒化学社製，エポラック G-2700PF）で成形された 新日本コア社製ハニカムコア（品番 FR-14-120）を 用い，これを表面材の FRP 板の成形と同時にステン レス製の金型内で接着し，サンドイッチ構造としたも のである．表面材は，ガラスチョップドストランド マット $\left(3.8 \mathrm{~N} / \mathrm{m}^{2}\right) 2$ 層と不飽和ポリエルテル樹脂で 構成し, 芯材のハニカムコアはセル径が $14 \mathrm{~mm}$, 高 さが $22.0 \mathrm{~mm}$ で，密度は $1200 \mathrm{~N} / \mathrm{m}^{3}$ となっている. なお表面材，心材とも FRP 部分のガラス繊維含有率 はほほ $30 \mathrm{wt} \%$ となっている。

Fig. 1 は表面材，心材を FRP で構成したハニカム サンドイッチ板の構造と断面寸法を示したものである. 心材の FRP ハニカムコアはせん断応力に，表面材の

$\dagger$ 原稿受理 平成 3 年 1 月 10 日 Received Jan. 10, 1991

* 正会 員 東京医科歯科大学医用器材研究所 東京都千代田区神田駿河台, Institute of Medical and Dental Engineering, Tokyo Medical and Dental University, Surugadai, Kanda, Chiyoda-ku, Tokyo

** トピー工業(株)技術本部 豊橋市明海町, Topy Industries, Akemi_cho, Toyohashi 


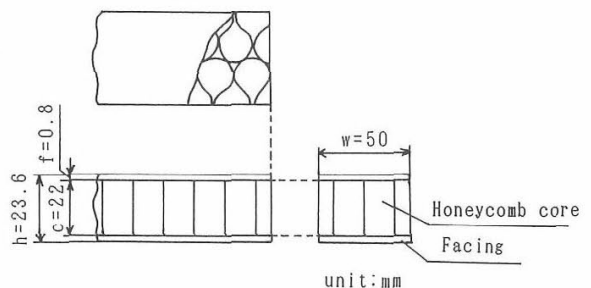

Fig. 1. Structure and dimension of cross section of FRP honycomb sandwich.

FRP 板は曲げ応力に抵抗する部材として設計されて いる.

通常ハニカムサンドイッチ材の破壊は負荷状態に よって曲げ破壊とせん断破壊とが共存した形で生じる。 したがってこのような破壊状況を想定して，曲げおよ びせん断破壇となる負荷状況を設定した。Fig. 2 は 3 点曲げ試験によって得られた FRP 製ハニカムサンド イッチ板の破壊様相を示したもので，曲げ破壊では表 面材の引張破壊とハニカムコアと表面材とのはく離が, またせん断破壊ではハニカムコアのせん断破壊と最終 段階での表面材の引張破壊とが生じる。またこのとき 得られたサンドイッチ材の曲げ破壊強さ $\sigma_{\mathrm{b}}$ は

$$
\sigma_{\mathrm{b}}=201.9 \mathrm{MPa}
$$

となり,またせん断破壊強さ $\tau_{\mathrm{b}}$ は

$$
\tau_{\mathrm{b}}=2.69 \mathrm{MPa}
$$

と求められた。なおこれらの結果は繰返し 5 本ずつの 試験で得られた平均值を示したものである。したがっ て両破畩応力の比は

$$
\sigma_{\mathrm{b}} / \tau_{\mathrm{b}}=75.0
$$

となっている.

\section{3 浸漬液の選択と組成}

FRP 製ハニカムサンドイッチが地中に埋設される ことを想定して浸漬液を選定した。 Table I は日本の 土壤についての $\mathrm{pH}$ 值の例を示したものである゙。一般 には土壤は酸性のところが多いとされているが，中に

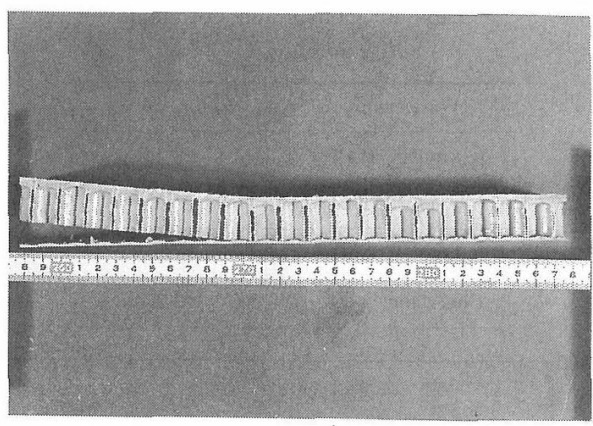

(a) Flexural fracture

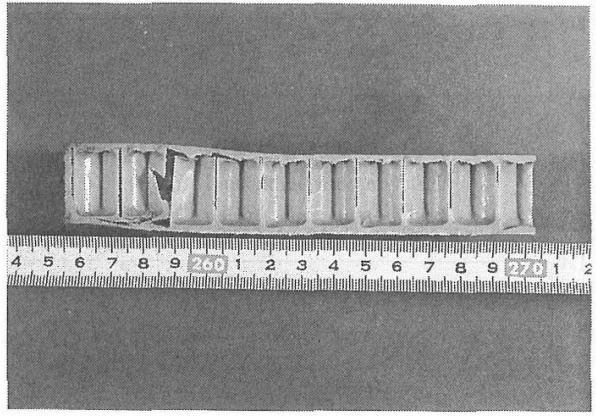

(b) Shear fracture

Fig. 2. Flexural and shear mode fracture tested by static test method.

は表に示されるようなアルカリの土壤も存在する。

しかし一般にFRPのマトリックスである不飽和ポ リエステル（UP）は酸には安定であるがアルカリ性 溶液中では加水分解し, 劣化することが知られている。 そこでこのような状況を考虑し，より過酷な浸漬溶液 として Table II に示す組成で, $\mathrm{pH}$ 值 9.0 9.4のアル カリ緩衝液を作成し，緩衝液中でクリープ試験を行 なった. Fig. 3 は所定のアルカリ緩衡溶液中にあらか じめ試験片を浸漬して曲げ強さとせん断強さの経時変

\begin{tabular}{|c|c|c|c|c|c|c|c|}
\hline & \multirow{2}{*}{$\begin{array}{l}\text { Drainage } \\
\text { qualities }\end{array}$} & \multirow{2}{*}{$\begin{array}{l}\text { Resistivity } \\
\quad(\Omega-\mathrm{cm})\end{array}$} & \multirow{2}{*}{$\mathrm{pH}$} & \multicolumn{4}{|c|}{ Water-soluble anions (mg/kg) } \\
\hline & & & & $\mathrm{Cl}^{-}$ & $\mathrm{SO}_{4}{ }^{2-}$ & $\mathrm{HCO}_{3}{ }^{-}$ & $\mathrm{NO}_{3}^{-}$ \\
\hline Sinnanyou & Poor & 7980 & 6.2 & 40 & 54 & 173 & 134 \\
\hline Amagasaki & Average & 37680 & 6.4 & 37 & 49 & 131 & 5098 \\
\hline Edogawa & Poor & 11252 & 9.4 & 18 & 450 & 152 & 25 \\
\hline Setagaya & Average & 17961 & 6.8 & 104 & 644 & 30 & 2936 \\
\hline Kumagaya & Average & 3000 & 7.1 & 121 & 381 & 82 & 740 \\
\hline Kashiwazaki & Good & - & 6.0 & 11 & 10 & 158 & 5 \\
\hline Edogawa (B) & Poor & 5966 & 7.8 & 463 & 1368 & 275 & 4 \\
\hline Setagaya (B) & Average & 11304 & 6.5 & 35 & 35 & 74 & 4650 \\
\hline
\end{tabular}
化を調べたものである。 その結果，試験片の浸漬時間

Table I. Example of soil $\mathrm{pH}$ values in Japan.

(notes) 1) $\mathrm{pH}$ and water-soluble anions value are result of analysis at dig up the specimen. 2 ) From $\lceil$ Instances of corrosion and countermeasure $\rfloor$ compiled by corrosion and corrosion protection association. 
Table II Constitutents of alkali buffer solution.

\begin{tabular}{c|c}
\hline Water-solution & Ratio (vol \%) \\
\hline $0.1 \mathrm{~mol} / 1 \mathrm{H}_{3} \mathrm{BO}_{3}$ & 25 \\
\hline $0.1 \mathrm{~mol} / 1 \mathrm{KCl}$ & 25 \\
\hline $0.1 \mathrm{~mol} / 1 \mathrm{NaOH}$ & 26.4 \\
\hline City water & 23.6 \\
\hline
\end{tabular}

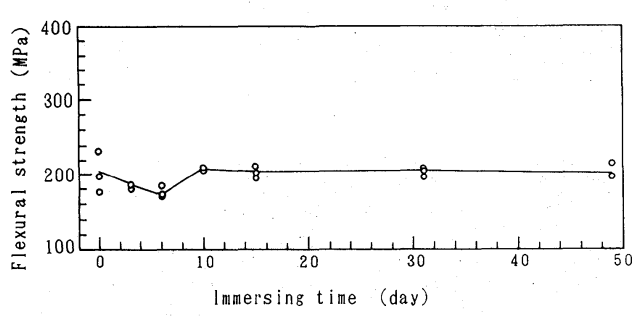

(a) Relation between flexural strength and dipping time in water.

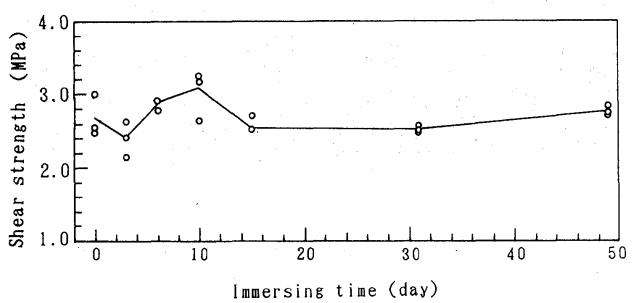

(b) Relation between shear strength and dipping time in water.

Fig. 3. Relation between strength of FRP honycomb sandwich and dipping time in water.

が 15 日を越えると試験片の曲げおよびせん断強さは 一定值を示すようになり，特性值のバラツキも少なく なる、そこでクリープ試験に供する試験片はすべて 15 日間以上の予備浸漬を行なった後，クリープ試験 を実施した。

\section{$4 \cdot 1$ 負荷応力}

\section{4 クリープ試験方法}

試験片に一定曲げ応力が加わる装置として 4 点曲げ 方式を採用した。しかしサンドイッチ板は負荷方式に よってせん断応力で破壊することから，サンドイッチ 板の機械的特性を基礎に曲げ破壊とせん断破壊とに よってクリープ破壊する場合を区別するために，4 点 曲げ試験方法による荷重点と支持点との位置を決定し た。

Fig. 4 はクリープ試験を行なう 4 点曲げ方法を示し たものであるが，この時 4 点曲げによってサンドイッ チ板に生じる曲げ応力 $\sigma$ は

$$
\sigma=\frac{M}{Z}=\frac{P}{2} \cdot \frac{a}{Z}
$$

ここで, $M:$ 曲げモーメント,

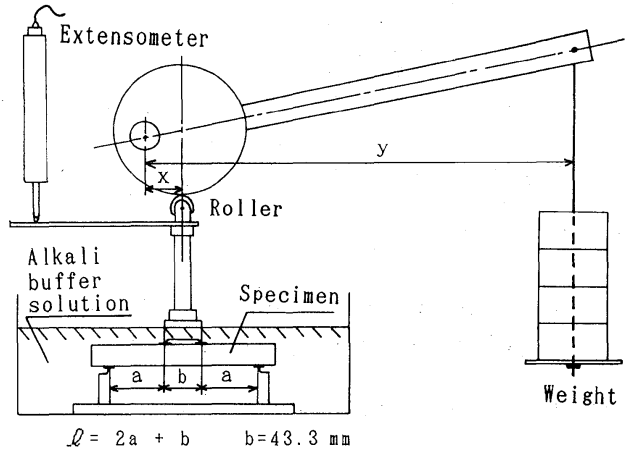

Fig. 4. Flexural and shear testing apparatus.

$$
Z: \text { 断面係数 }=\frac{W f(h+c)}{2}
$$

となり，またせん断応力 $\tau$ は

$$
\tau=\frac{P}{W(h+c)}
$$

と与えられる.このようなことを基礎に Fig. 1 に示し た試験片寸法を用い，試験板が曲げ破壊となる条件を 求めると式 (1), 式 (2) に $\sigma>201.9 \mathrm{MPa}$ おび $\tau$ $<2.69 \mathrm{MPa}$ の条件を代入して, 外側スパン $a$ の条件 を求めると

$$
\begin{aligned}
& P a / w f(h+c)>201.9 \\
& P / w(h+c)<2.69
\end{aligned}
$$

となり，これより $P$ を消去すると曲げ破壊となる条 件は

$$
a>\sigma_{\mathrm{b}} \cdot f / \tau_{\mathrm{b}}=75.0 \cdot \mathrm{f} \mathrm{mm}
$$

と与えられる．そこでこのようなことを配慮して， Fig. 5 に示すような外側スパン $a$ を定め, 曲げクリー プ試験とせん断クリープ試験を行なった。なおこのと き各試験によって生じる垂直応力 $\sigma$ とせん断応力 $\tau$ との関係は曲げ試験では $\sigma / \tau=154$, せん断試験では $\sigma / \tau=54$ となっており, それぞれの試験方法では所 定の負荷応力状態になることが確認される：したがっ

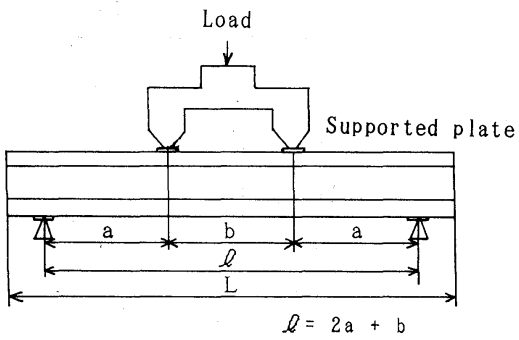

\begin{tabular}{lrccc}
\hline Test method & $a(m \mathbb{m})$ & $b(\mathbb{m} \mathbb{n})$ & $\ell(\mathbb{m} \mathbb{m})$ & $L(\mathbb{m m})$ \\
\hline Flexural test & 123.35 & 43.3 & 290 & 300 \\
Shear test & 43.30 & 43.4 & 130 & 150
\end{tabular}

Fig. 5. Loading system of 4 point flexural test, and inner and outer spans of flexural and shear creep test. 


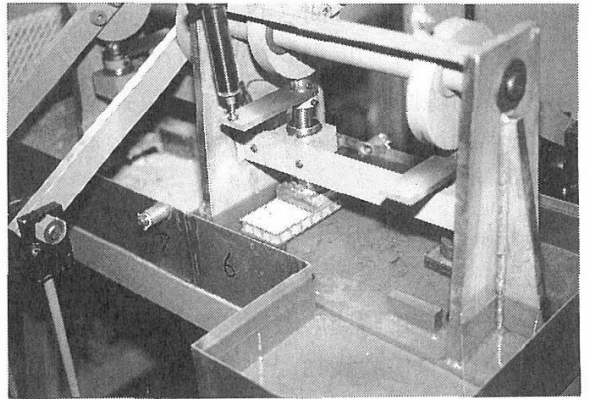

Fig. 6. Creep testing apparatus with vessel of dipping water.

てこれらの負荷装置を所定の浸漬液の容器中に埋入し， 浸漬液中でのクリープ試験を行なった.

\section{$4 \cdot 2$ 負荷装置}

Fig. 6 はクリープ試験用の曲げ負荷装置と浸漬装置 を示す．クリープ試験は所定の溶液中で行なうために， 溶液中に浸漬して曲げおよびせん断応力が加えられる ようになっている. また所定の負荷応力はテコの原理 を応用して，試験片に一定の荷重が加えられるように なっている．ここで荷重の調整は小さな負荷応力の変 化にも刘応できるようにテコの比 $\mathrm{x} / \mathrm{y}$ を $\mathrm{x} / \mathrm{y}=1 / 10$ と設定した。また負荷時間の経過に伴なって変化する 試験片のたわみ量は荷重点の垂直変位の生じる位置に 直接自動記録用の変位計を取り付け，破壊に至るまで の試験片のたわみをリアルタイムで計測した。

\section{$4 \cdot 3$ 試験方法}

クリープ試験の負荷応力は静的曲げおよびせん断強 さ試験の結果を基礎に，曲げ応力については曲げ強さ の 70 80\%の範囲で 3 水準の負荷応力を設定し, せ ん断応力についてはせん断強ざの 65～75\% 範囲内で 3 水準の負荷応力を設定した.

なお 15 日間以上無負荷状態でアルカリ緩衝液に浸 漬したサンドイッチ板の破壊強さは各 5 本ずつの静的 強さの平均值を求めたもので，曲げ強さは 204.0 $\mathrm{MPa}$ ，せん断強さは $2.51 \mathrm{MPa}$ となって，おのおの の破壊強さは浸漬をしない試験片とほぼ同等の試験結 果を得た。

\section{5 クリープ試験結果}

クリープ試験は所定の溶液中で曲げおよびせん断試 験を行ない, 各試験について 3 水準の負荷応力を設定 してクリープ破壊時間を求め，これらのデータをもと に $10^{6}$ 時間（約 114 年に相当）に対するクリープ寿命 の推定を行なった.

\section{$5 \cdot 1$ クリープ変形-時間線図}

Fig. 7 は曲げおよびせん断クリープ試験によって得 られたクリープ変形一時間線図を示したものである. 負荷応力に対するクリープ変形は曲げクリープでは

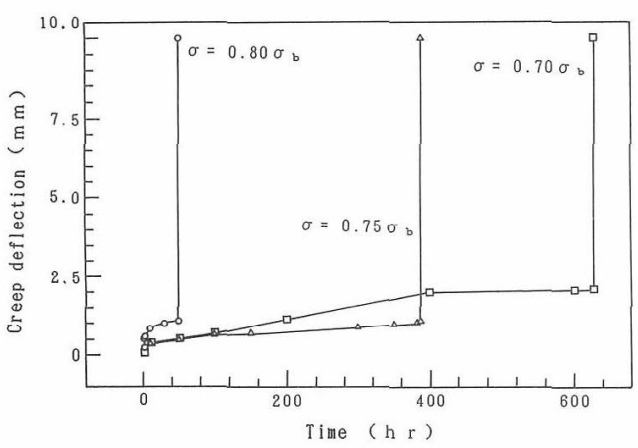

(a) Relation between loading time and creep displacement in flexural creep test.

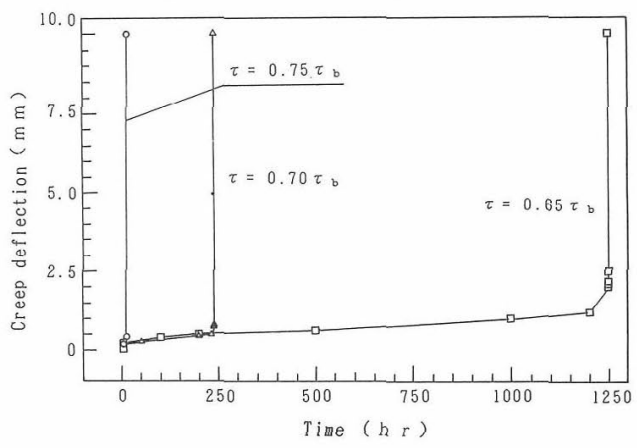

(b) Relation between loading time and creep displacement in shear creep test.

Fig. 7. Relation between loading time and creep displacement in creep test.

(Fig. 7 (a)）表面材の破壊となることから負荷過程で はクリープ変形は少なく, 破壊時間近傍で急激な変形 とともに突然破壊する。しかしせん断クリープでは (Fig. 7 (b)) 八ニカムコア材の破壊となることからク リープ変形は負何時間の増加とともに徐々に増大し急 激な破壊に至る。このことは表面忉は常にアルカリ緩 衝液にさらされていることによるFRP 材の劣化と八 ニカムコア材のせん断変形がコア材の形状的な要因も 含めて徐々に变化するため, 両応力形態によって, ク リープ変形の挙動が異なるものと考えられる．

\section{$5 \cdot 2$ クリープ特性}

Fig. 8 は浸漬無負荷の試験体の曲げ強さをもとにそ れぞれ 70\%，75\%，80\% の応力を負荷して得られた， クリープ破壞強さー時間線団を示したものである。試 験片は同じ応力水準について繰返し 3 本ずつの試験を 行ない, それぞれの結果をもとに最小 2 乗法に従い直 線式を決定した。その結果, 曲げクリープ破壊強ざ時間線図は

$$
\sigma_{\mathrm{B}}=166-3.01 \ln T(\mathrm{MPa})
$$

と表示される. また Fig. 8 には標準偏差 $\sigma$ をベース に $\pm 3 \sigma$ の直線式を併記した.

またせん断応力についても浸漬無負荷の試験体のせ ん断強さをもとにそれぞれ $65 \% ， 70 \% ， 75 \%$ の応力 


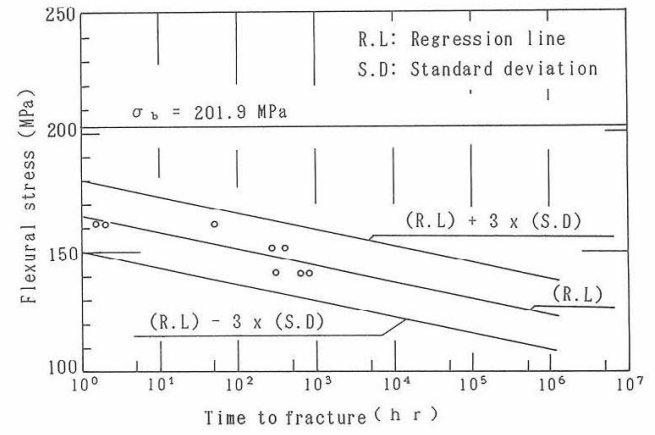

Fig. 8. Relation between creep flexural strength and fracture time.

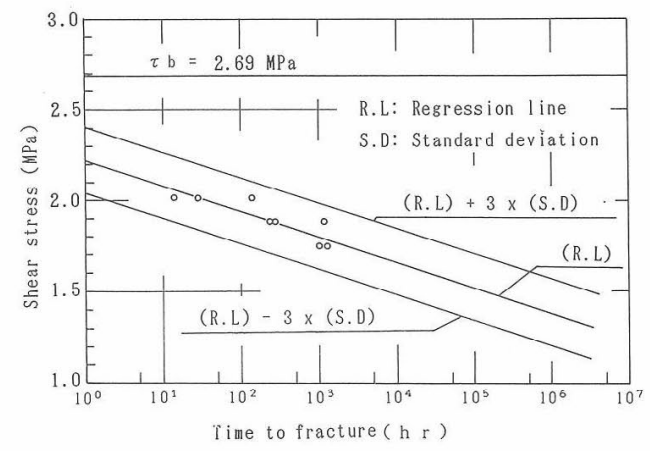

Fig. 9. Relation between creep shear strength and fracture time.

を負荷して, クリープ破壞強さ-時間線図を作成した。 Fig. 9 はせん断応力についてのクリープ破壊強さ一時 間曲線を示したもので，曲げクリープの場合と同様に 同じ応力水準について繰返し 3 本ずつの試験を行ない それぞれの結果をもとに最小 2 乗法に従い直線式を決 定した.

その結果せん断クリープ破壞強さ一洔間線図は

$$
\tau_{\mathrm{B}}=2.20-0.06 \ln \mathrm{T}(\mathrm{MPa})
$$

と表示される。またFig. 9 には標準偏差 $\sigma$ をべース に $\pm 3 \sigma$ の直線式を併記した。

\section{$5 \cdot 3$ クリープ寿命}

クリープ試験では曲げ応力とせん断応力との負荷状 態を設定して，負荷応力をパラメータにクリープ破淕 時間を測定した。そ結果曲げ応力状態では最小の真 荷応力は静的破壇応力の $70 \%$ でクリープ破㵝時間 $\sigma$ 。 平均值が 586.9 時間（24.5 日）であった。しかし負葆 応力の増大に伴なってクリープ破壊時間は片対数表示 で直線的に減少することから両者の関係に直線則を邉 用した，そこでこのような結果をさらに拡張してクリ ープ負荷時間 $T, T=10^{6}$ 時間のクリープ破壞強さを 求めると $\left(\sigma_{\mathrm{B}}\right)_{T=106}$ は

$$
\left(\sigma_{\mathrm{B}}\right)_{T=10^{6}}=121 \mathrm{MPa}
$$

となる。一方，せん断強さについても本実験で測定し たクリープ破壊時間はせん断強さの $65 \%$ で平均クリ
ープ破壊時間が 1168 時間（48.7日）であったが，こ れについても 3 水準の応力レベルで行なったクリープ 破壊强さ一時間線図が片対数表示で直線式で表される ことから $T=10^{6}$ 時間のクリープ破壞強さを求めると $\left(\tau_{\mathrm{B}}\right)_{T=10^{\circ}}$ は

$$
\left(\tau_{\mathrm{B}}\right)_{T=10^{6}}=1.20 \mathrm{MPa}
$$

と求まる.

またクリープ破壊時間の増加に伴うクリープ破壞強 さの低下の割合は実験式 (3) と式(4)の勾配で示され, それぞれの值は曲げ強さの 3.01 に比べ，せん断強ざ は 0.06 と小さいことが示される.

しかしこのことはせん断応力による劣化に比べ曲げ 応力による劣化のほうが大きいように見えるが，サン ドイッチ板の曲げ強さはせん断強さに比べて 75 倍程 度大きい，そこで両応力に対するクリープ破壞時間の 増加に伴うクリープ破壊強さの低下の比を調べると両 式の勾配の比は 50 倍となっており，両応力に対する 破壊強さを基礎に考えると曲げ応力の劣化に比べ，せ ん断応力の劣化の割合のほうが大きいことが示される. したがって浸漬液中のクリープ試験による劣化はむし ろ曲げ応力に比べ，せん断応力による劣化のほうが相 対的に大きいことが示される。

6 FRP ハニカムサンドイッチ材のクリープ

破壊

Fig. 10 はFRP ハニカムサンドイッチ材のクリー

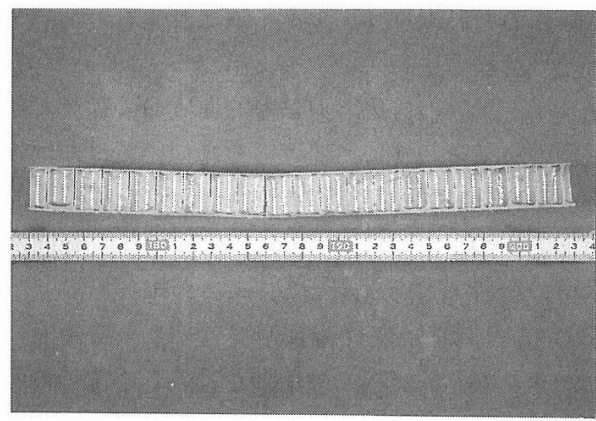

(a) Flexural fracture

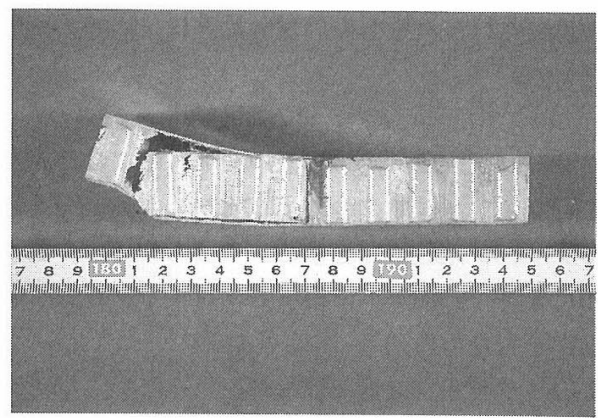

(b) Shear fracture

Fig. 10. Creep fracture pattern of FRP honycomb sandwich construction. 
プ破壊の様相を示したもので，曲げクリープは $\sigma$ $=0.75 \sigma_{\mathrm{b}}$, せん断クリープは $\tau=0.70 \tau_{\mathrm{b}}$ の負荷応力で 破壊した試験片である．曲げクリープ破壊は表面材が 引張破壊し，破壊と同時に心材が接着面と横せん断と によって破壊する。しかし曲げによる残留変形はクリ 一プ変形による破壊にもかかわらず少ない．また静的 曲げ破壊と異なり，表面材と心材との接着面での破壊 は 2 次的な破壊として生ずるため損傷の領域も狭い範 囲になっている. せん断クリープ破壊は心材が横せん 断により破壊し，表面材の引張破壊と表面材と心材と の界面破壊が 2 次的な破壊となって現われる。した がって静的なせん断破壊と異なりせん断クリープ破壊 では領域が広い範囲に拡大しているのが特徴である。

\section{7 結}

\section{言}

FRP 製ハニカムサンドイッチ板は軽量で，かつ高 い風性を有することから軽量ブロックとして地中に埋 設して使用されている.ここではこのようなサンド イッチ板のクリープ特性を明らかにするため, 我が国 における土中での $\mathrm{pH}$ 值の資料をもとにアルカリ緩衝 液を調整し, 所定の溶液を設定し溶液中でのクリープ 試験を行なった結果，次のような結果を得た。

（1） FRP 製ハニカムサンドイッチ板に横荷重の加 わることを想定し, 板に加わる応力を曲げ応力とせん 断応力として分けて, クリープ試験を行ない, 両負荷 応力についてのクリープ破壊強さ-時間 $\left(\sigma_{\mathrm{B}}-T\right)$ 線図 を実験により求めた。曲げクリープ破壊強さ $\sigma_{\mathrm{B}}$ は片 対数表示で次のような直線式が表示された.

$$
\sigma_{\mathrm{B}}=166-3.00 \ln T(\mathrm{MPa})
$$

一方，せん断クリープ破壊強さ $\tau_{\mathrm{B}}$ は

$$
\tau_{\mathrm{B}}=2.20-0.06 \ln T(\mathrm{MPa})
$$

と表示されることが明らかとなった。

（2）また上記の実験式をもとに $T=10^{6}$ 時間でのク リープ寿命を推定した。 その結果曲げ破壊クリープ強 さでは $\left(\sigma_{\mathrm{B}}\right)_{T=10^{6}}=108 \mathrm{~Pa}$ となり, せん断クリープ強さ は $\left(\tau_{\mathrm{B}}\right)_{T=10^{6}}=1.20 \mathrm{MPa}$ となり，これらのクリープ強さ は静的強さに比べ，曲げ強さについては $52.9 \%$ ，せ ん断強さについては $47.8 \%$ となることが明らかに なった。またせん断クリープ破壊は曲げクリープ破壊
に比べ，クリープ応力による劣化速度は $1 / 50$ 程度と 小さいことが確認された.

(3) 曲げクリープによる破壊では一般に表面材の溶 液中での劣化の影響を受けやすいが，負荷過程でのク リープ変形は比較的少ない. しかし破壊時近傍では急 激な変形とともにぜい性的な破壊となる．またせん断 応力によるクリープ破壊は曲げクリープに比べ，変形 量の増大も緩慢でその量も小さい. したがって，クリ 一プせん断破壊は負荷時間の経過とともに徐々に進行 し破壊近傍での変形量もクリープ曲げ破壊のような急 激な破壊は現われない。

（4）また曲げクリープ破壊とせん断クリープ破壊と はその破壞の様相も異なり，両破壊は破壊の状況にお いても明らかに区別できるものであることを確認した。 なお本研究に関し使用した FRP 製ハニカムコアサ ンドイッチ板は新日本コア(株)からご提供いただいたも のでここに厚くお礼申し上げる.

(平成 2 年10月19日 日本複合材料学会第15回複合材料シンポジウムに て講演)

\section{参 考 文 献}

1). “先端複合材料”, 日本機械学会編, p. 9 (1990).

2 ) “強化プラスチックハンドブック”, 強化プラスチックス 技術協会編，p.389（1975）日刊工業新聞社刊

3 ) “複合材料ハンドブック”，日本複合材料科学会編，p. 235 （1989）日刊工業新聞社刊

4 ) A. F. Johnson, G. D. Sims and F. Ajibade, Composites, 21, 319 (1990)

5 ) M. Akay and R. Hanna, Composites, 21, 325 (1990).

6 ）島村昭治，宮入裕夫，“サンドイッチ構造”， p. 22 （1974）日刊工業新聞社刊

7) A. F. Johnson and G. D. Sims, Composites, 17, 321 (1986).

8 ) R. Jones, W. Broughton, R. F. Mousley and R. T. Potter, Composite Struct, 3, p. 167 (1985).

9 ) “腐食と対策事例集”, p. 47 (1985) 腐食防食協会編

10）“FRP 設計便覧”， p. 150 (1979）強化プラスチックス 技術協会編 